\title{
Synthesis and Thermal Properties of Poly(ethylene glycol)-polydimetylsiloxane Crosslinked Copolymers
}

(Sintesis dan Sifat Terma Kopolimer Taut Silang Poli(etilena glikol)-polidimetilsiloksana)

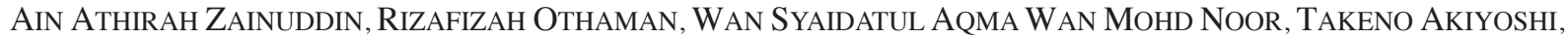
TAKAHASHI SHINYA \& FARAH HANNAN ANUAR*

\begin{abstract}
Poly(ethylene glycol)-polydimethylsiloxane (PEG-PDMS) crosslinked copolymers with mol ratios PEG:PDMS:Glycerol of 5:3:2, 6:2:2 and 7:1:2 have been prepared and characterized. The synthesis of the copolymers was carried out by the reaction between hydroxyl groups of PEG, PDMS and glycerol with isocyanate groups of 1,6-hexamethyelene diisocyanate (HMDI). In the reaction, glycerol was acted as the cross linker. The copolymers were then characterized by FTIR spectroscopy. The thermal behaviour was investigated by DSC and TGA. Based on FTIR results, the crosslinked structure of the copolymers was confirmed by the presence of absorption peak at 3350 and $1710 \mathrm{~cm}^{-1}$ which indicated the $(-\mathrm{N}-\mathrm{H})$ stretching and carbonyl $(-\mathrm{C}=\mathrm{O})$ correspond to urethane links. This showed that the hydroxyl groups of PEG, $P D M S$ and glycerol have reacted to isocyanate groups of HMDI. The copolymers showed melting temperature $\left(T_{m}\right)$ of $P E G$ segments from $22^{\circ} \mathrm{C}$ to $27^{\circ} \mathrm{C}$ and glass transition temperature $\left(T_{g}\right)$ from $-11^{\circ} \mathrm{C}$ to $-6^{\circ} \mathrm{C}$. Meanwhile, the PDMS segment showed values from $-53^{\circ} \mathrm{C}$ to $-56^{\circ} \mathrm{C}$ for $T_{m}$, and $T_{g}$ from $-118^{\circ} \mathrm{C}$ to $-122^{\circ} \mathrm{C}$. Data obtained from the thermal analysis indicate that thermal stability increases with increasing PDMS mol ratio.
\end{abstract}

Keywords: Crosslinked copolymer; polydimethylsiloxane; poly(ethylene glycol); thermal

\section{ABSTRAK}

Kopolimer taut silang poli(etilena glikol)-polidimetilsiloksana (PEG-PDMS) dengan nisbah PEG:PDMS:Gliserol 5:3:2, 6:2:2 dan 7:1:2 telah disediakan dan dicirikan. Sintesis kopolimer dilakukan dengan tindak balas kumpulan hidroksi PEG, PDMS dan gliserol dengan kumpulan isosianat 1,6-heksametilena diisosianat (HMDI). Dalam tindak balas ini, gliserol berperanan sebagai agen taut silang. Kesemua kopolimer kemudiannya dicirikan oleh spektroskopi inframerah (FTIR). Ciri terma kopolimer dilihat berdasarkan analisis kalorimetri imbasasan kebezaan (DSC) dan analisis termogravimetrik (TGA). Berdasarkan spektrum inframerah, struktur taut silang kopolimer ditentukan oleh kehadiran puncak serapan pada 3350 dan $1710 \mathrm{~cm}^{-1}$ yang menunjukkan regangan $(-\mathrm{N}-\mathrm{H})$ dan kumpulan karbonil $(-\mathrm{C}=\mathrm{O})$ yang sepadan dengan pautan uretana. Ini menunjukkan bahawa kumpulan hidroksi PEG, PDMS dan gliserol telah bertindak balas dengan kumpulan isosianat HMDI. Kopolimer menunjukkan suhu lebur $\left(T_{m}\right)$ bagi segmen PEG daripada $22^{\circ} \mathrm{C}$ hingga $27^{\circ} \mathrm{C}$ dan suhu peralihan kaca $\left(T_{g}\right)$ daripada $-11^{\circ} \mathrm{C}$ hingga $-6^{\circ} \mathrm{C}$. Sementara itu, segmen PDMS menunjukkan nilai daripada $-53^{\circ} \mathrm{C}$ hingga $-56^{\circ} \mathrm{C}$ untuk $T_{m}$, dan $T_{g}$ daripada $-118^{\circ} \mathrm{C}$ hingga $-122^{\circ} \mathrm{C}$. Kestabilan degradasi kopolimer pula meningkat apabila nisbah mol PDMS meningkat.

Kata kunci: Kopolimer taut silang; polidimetilsiloksana; poli(etilena glikol); terma

\section{INTRODUCTION}

Polyurethane (PU) is a polymer which consists of urethane links in the main chains. PU can be synthesized by the reaction of polyol, isocyanate and occasionally chain extender is added to modify the properties of the polymer. Segmented PU has been widely studied over the past years because it gives merging of biocompatibility, elastomeric properties and thermoplastic processing conditions (Hong et al. 2010; Wang et al. 2009; Wu et al. 2000). Therefore, it has various applications in industries and daily uses. It has been commercially used as coatings, foams, adhesives, sealants, synthetic leathers, membranes, elastomers, as well as in biomedical applications (Chattopadhyay et al. 2009).
Alternating soft and hard segments in PU suggest distinctive possibilities of designed polymers by varying the block length and composition (Shokrolahi et al. 2014). Thermal stabilities of PU are very important properties which has attracted much attention in the literature over the past decades (Król et al. 2010; Yeh et al. 2010). Soft segment blocks usually have low glass transition temperature $\left(\mathrm{T}_{\mathrm{g}}\right)$ and normally are polyether or polyester (Hood et al. 2010; Wang et al. 1983). Thermal stability of PU is usually up to $250^{\circ} \mathrm{C}$ and the hard segments of urethane linkages initiated decomposition (Tyagi et al. 1984). Most of the polymeric materials usually have degradation problems especially at high temperature and it can be resolved by introducing poly(ethylene glycol) 
(PEG) segments into the polymer backbone (Sung-Il et al. 2000).

PU copolymers with poly(ethylene glycol) (PEG) in the backbone can enhance degradation since PEG has good biodegradability (Kawai 1987; Kawai et al. 1996). Polysiloxanes are versatile materials that have been used in many applications due to its diversity of properties and processing technologies (Askari et al. 2015). Moreover, PU based on polydimethylsiloxane (PDMS) can also overcome the degradation problem (Yeh et al. 2010). PDMS has been widely studied due to its properties such as high heat resistance, good biocompatibility and environmental friendly (Zhang et al. 2013). PDMS has very low glass transition temperature $\left(\mathrm{T}_{\mathrm{g}}\right)$ which is approximately at $-125^{\circ} \mathrm{C}$ and low surface energy (Clarson et al. 1993). The thermal stability and degradation of polydimethylsiloxanebased PUs have been extensively studied because of the great importance of the PU which lies in its ease of processing and diversity of applications (Chuang et al. 2004; Hamdani et al. 2009).

In this study, poly(ethylene glycol)polydimethylsiloxane crosslinked copolymer with three different compositions were synthesized by the reaction of terminal hydroxyl groups of PEG, PDMS and glycerol with isocyanate of HMDI. The glycerol was added in the reaction to act as cross linker. The copolymers were characterized to determine the structure and the thermal behaviour. The structure of the copolymers was identified using FTIR spectroscopy. Then, the thermal stability of the copolymers was determined by DSC and TGA. To the best of our knowledge, no study has been reported on the thermal properties of poly(ethylene glycol)-polydimethylsiloxane crosslinked copolymers.

\section{MATERIALS AND METHODS}

\section{MATERIALS}

Poly(ethylene glycol) (PEG) ( $\left.\mathrm{M}_{w}, 1,500 \mathrm{~g} / \mathrm{mol}\right)$, polydimethylsiloxane-bis-hydroalkyl (PDMS) (M 5,600), 1,6-hexamethylene diisocyanate (HMDI, 98\%) and tin(II)2ethylhexanoate $\left(\mathrm{Sn}(\mathrm{Oct})_{2}, 95 \%\right)$ were obtained from Sigma Aldrich. Glycerol $\left(\mathrm{M}_{w} 92 \mathrm{~g} / \mathrm{mol}\right)$ from R\&M Chemicals was used as cross linker. These reagents were used as received. Chloroform $\left(\mathrm{CHCl}_{3}, 99 \%\right)$ was obtained from R\&M Chemicals and dried over calcium hydride $\left(\mathrm{CaH}_{2}\right.$, Sigma Aldrich) and refluxed prior to use.

\section{SYNTHESIS OF PEG-PDMS CROSSLINKED COPOLYMERS}

Poly(ethylene glycol)-polydimetylsiloxane crosslink copolymers (PEG-PDMS PU) with mol ratios of PEG:PDMS:Glycerol 5:3:2, 6:2:2 and 7:1:2 have been prepared by varying the mol ratio of PEG:PDMS and keeping the ratio of glycerol and HMDI constant. PEG and PDMS having two hydroxyl groups at the end of the chain were reacted with isocyanate group of 1,6-hexamethylene diisocyanate such as the following reaction equation in Figure 1.

The synthesis of copolymers was carried out in a $50 \mathrm{~mL}$ reaction flask with glass stopcock equipped with magnetic stir bar. First, PEG and PDMS were dissolved in $30 \mathrm{~mL}$ of dry chloroform. After that, HMDI was added in the flask. Subsequently, $\mathrm{Sn}(\mathrm{Oct})_{2}$ catalyst and glycerol were added in the mixture. The ratio of $\mathrm{Sn}(\mathrm{Oct})_{2}$ added was $1 \mathrm{~mol}$ of PEG to $2 \mathrm{~mol}$ of $\mathrm{Sn}(\mathrm{Oct})_{2}$. The reaction was carried out for $3 \mathrm{~h}$ at $40^{\circ} \mathrm{C}$ in inert atmosphere. After that, the synthesized copolymer was casted in Teflon plate with dimensions of $15 \times 15 \mathrm{~cm}$ to form a thin film. The plate was left in the fume hood for $24 \mathrm{~h}$ to let the solvent dry. Then, the film was peeled from the plate and vacuumed overnight to remove the traces of solvent.

The copolymers were notated as aEbD. E and D were denoted as PEG and PDMS, respectively. Meanwhile, $a$ and $b$ were denoted as the mol ratio of PEG and PDMS respectively. For example, 5E3D indicated that the sample was synthesized by ratio of $5 \mathrm{~mol}$ of PEG and $3 \mathrm{~mol}$ of PDMS. The three compositions of the copolymers is showed in Table 1.

\section{CHARACTERIZATION}

\section{FTIR SPECTROSCOPY}

The infrared absorption spectra of the copolymers were obtained by Perkin Elmer Spectrum 400 FTIR Spectrometer. The spectrometer was operated using Attenuated Total Reflectance (ATR) mode. The spectrum were recorded from 4000 to $600 \mathrm{~cm}^{-1}$.
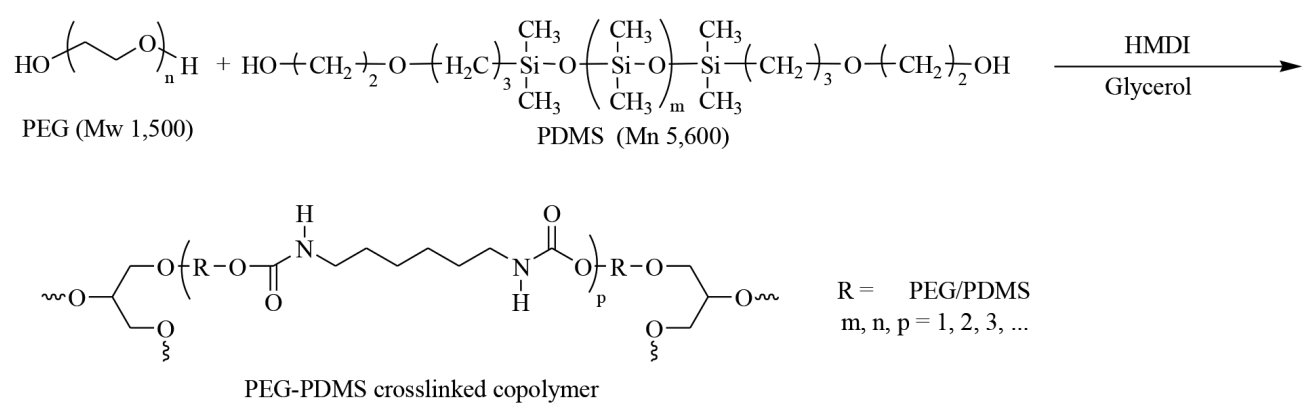
TABLE 1. The composition of PEG-PDMS crosslinked copolymers

\begin{tabular}{cccccc}
\hline Samples & $\begin{array}{c}\text { Weight } \\
\text { percentage of } \\
\text { PEG (\%) }\end{array}$ & $\begin{array}{c}\text { Weight } \\
\text { percentage of } \\
\text { PDMS (\%) }\end{array}$ & $\begin{array}{c}\text { Mol ratio } \\
\text { PEG:PDMS }\end{array}$ & $\begin{array}{c}\text { Mol ratio } \\
\text { HMDI }\end{array}$ & $\begin{array}{c}\text { Mol ratio } \\
\text { glycerol }\end{array}$ \\
\hline 5E3D & $30 \%$ & $70 \%$ & $5: 3$ & 20 & 2 \\
6E2D & $45 \%$ & $55 \%$ & $6: 2$ & 20 & 2 \\
7E1D & $65 \%$ & $35 \%$ & $7: 1$ & 20 & 2 \\
\hline
\end{tabular}

\section{DIFFERENTIAL SCANNING CALORIMETRY (DSC) ANALYSIS}

The measurements of glass transition temperature, $\mathrm{T}_{\mathrm{g}}$ and melting transition temperature, $T_{m}$ were carried out by using SII Seiko Instruments Inc. DSC 6200, Japan. The samples were heated at $-160^{\circ} \mathrm{C}$ up to $100^{\circ} \mathrm{C}$ with heating rate of $15^{\circ} \mathrm{C} / \mathrm{min}$. The mass of the samples was approximately $5 \mathrm{mg}$.

\section{THERMOGRAVIMETRY ANALYSIS}

The thermogravimetric analysis was performed by using SHIMADZU TA60ws. The samples were heated at heating rate $10^{\circ} \mathrm{C} / \mathrm{min}$ from $30^{\circ} \mathrm{C}$ to $600^{\circ} \mathrm{C}$ under nitrogen atmosphere with flow rate $20 \mathrm{~mL} / \mathrm{min}$.

\section{RESULTS AND DISCUSSION}

\section{SYNTHESIS OF PEG-PDMS CROSSLINKED COPOLYMERS}

The synthesis of PEG-PDMS crosslink copolymers was carried out by reaction of terminal hydroxyl groups of PEG, PDMS and glycerol with isocyanate groups of HMDI. The reaction between these two functional groups will form urethane links. The formation of urethane links showed that the individual homopolymer chain have been linked to the other chain via the links. Since isocyanate can react with hydroxyl group, it also may react with the glycerol to form crosslinked copolymers. There are many possibilities of the selectivity of the reaction. The isocyanate may link the PEG chain with other PEG chain, PDMS chain with other PDMS chain or PEG chain with PDMS. Other possibility was glycerol react with the isocyanate and then reacts with the homopolymer to form a crosslinked structure.

TABLE 2. FTIR absorption bands of PEG-PDMS crosslinked copolymers

\begin{tabular}{cc}
\hline Absorption bands $\left(\mathrm{cm}^{-1}\right)$ & Assignments \\
\hline 3350 & -N-H stretching \\
$2960-2870$ & $-\mathrm{C}-\mathrm{H}$ stretching \\
1710 & $-\mathrm{C}=\mathrm{O}$ stretching \\
1540 & $-\mathrm{C}-\mathrm{N}-\mathrm{H}$ bending \\
1620 & $-\mathrm{C}-\mathrm{N}$ stretching \\
1250 & Methyl in $-\mathrm{Si}_{-} \mathrm{CH}_{3}$ \\
\hline
\end{tabular}

\section{STRUCTURAL DETERMINATION OF THE PEG-PDMS CROSSLINKED COPOLYMERS}

The FTIR spectrum of the copolymers that have been obtained are shown in Figure 2 and summarized in Table 2. The absorption at $3350 \mathrm{~cm}^{-1}$ is corresponds to (-NH) stretching. In addition, it is found that absorption at 1523 $\mathrm{cm}^{-1}$ indicates the $(-\mathrm{C}-\mathrm{N}-\mathrm{H})$ bending and the absorption at $1736 \mathrm{~cm}^{-1}$ is identified as the carbonyl group $(-\mathrm{C}=\mathrm{O})$ (Wong \& Badri 2010). There is also absorption at 1616 $\mathrm{cm}^{-1}$ wavenumber which indicates $(-\mathrm{C}-\mathrm{N})$ stretching (Rangel-Vazquez et al.2014). These results are pointed to the urethane group in the copolymer chain thus confirming that the reaction between the hydroxyl and isocyanate groups has occurred. The sharp peaks at $2960-2870 \mathrm{~cm}^{-1}$ are associated to $\mathrm{CH}$ stretching for the copolymers. The absorption peak at $1250 \mathrm{~cm}^{-1}$ was assigned to the methyl group of the polydimethylsiloxane.

\section{THERMAL BEHAVIOUR OF PEG-PDMS CROSSLINKED COPOLYMERS}

Copolymers generally have two different temperatures of melting transition temperature $\left(\mathrm{T}_{\mathrm{m}}\right)$ and glass transition

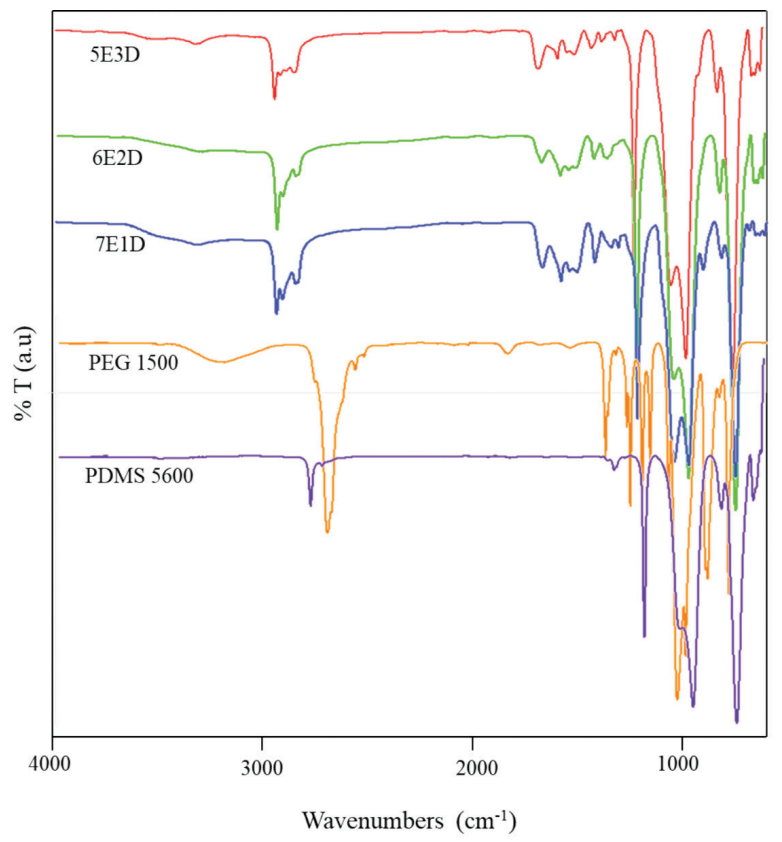

FIGURE 2. FTIR spectrum of PEG-PDMS crosslinked copolymers, PEG 1,500 and PDMS 5,600 
temperature $\left(\mathrm{T}_{\mathrm{g}}\right)$ (Badri et al. 2013). The $\mathrm{T}_{\mathrm{m}}$ and $\mathrm{T}_{\mathrm{g}}$ of PEG and PDMS segments in the copolymers are summarized in Table 3. In addition, the DSC curves of the copolymers are shown in Figure 3. Comparing between the three copolymers, the $T_{m}$ value of PEG segments increased from $23^{\circ} \mathrm{C}$ to $27^{\circ} \mathrm{C}$ for $5 \mathrm{E} 3 \mathrm{D}$ and $6 \mathrm{E} 2 \mathrm{D}$ and then decreased to $22^{\circ} \mathrm{C}$ for $7 \mathrm{E} 1 \mathrm{D}$. The same trend was also observed for $\mathrm{T}_{\mathrm{g}}$. There is an increment of $\mathrm{T}_{\mathrm{g}}$ values for $5 \mathrm{E} 3 \mathrm{D}$ and $6 \mathrm{E} 2 \mathrm{D}^{\mathrm{g}}$ from $-11^{\circ} \mathrm{C}$ to $-6^{\circ} \mathrm{C}$ and a reduction to $-9^{\circ} \mathrm{C}$ for 7E1D. However, the $\mathrm{T}_{\mathrm{m}}$ and $\mathrm{T}_{\mathrm{g}}$ of PDMS segments in the copolymers showed a trend. The values decreased as the mol ratio of PDMS decreased.

TABLE 3. Melting transition temperature $\left(\mathrm{T}_{\mathrm{m}}\right)$ and glass transition temperature $\left(\mathrm{T}_{\mathrm{g}}\right)$ of PEG and PDMS segments by DSC

\begin{tabular}{ccccc}
\hline \multirow{2}{*}{ Samples } & \multicolumn{2}{c}{$\mathrm{T}_{\mathrm{m}}\left({ }^{\circ} \mathrm{C}\right)$} & \multicolumn{2}{c}{$\mathrm{T}_{\mathrm{g}}\left({ }^{\circ} \mathrm{C}\right)$} \\
\cline { 2 - 5 } & PDMS segments & PEG segments & PDMS segments & PEG segments \\
\hline 5E3D & -53 & 23 & -118 & -11 \\
6E2D & -54 & 27 & -120 & -6 \\
7E1D & -56 & 22 & -122 & -9 \\
\hline
\end{tabular}

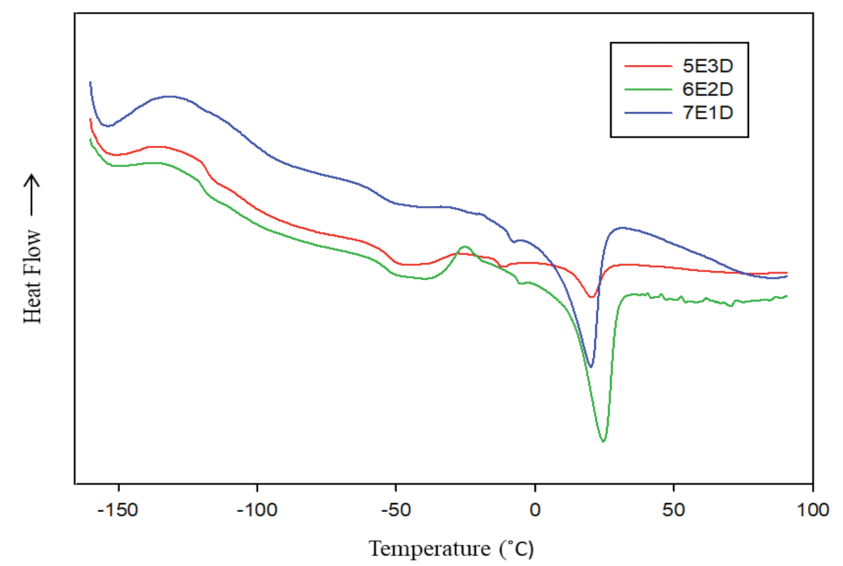

FIGURE 3. DSC curves of PEG-PDMS crosslinked copolymers

a)

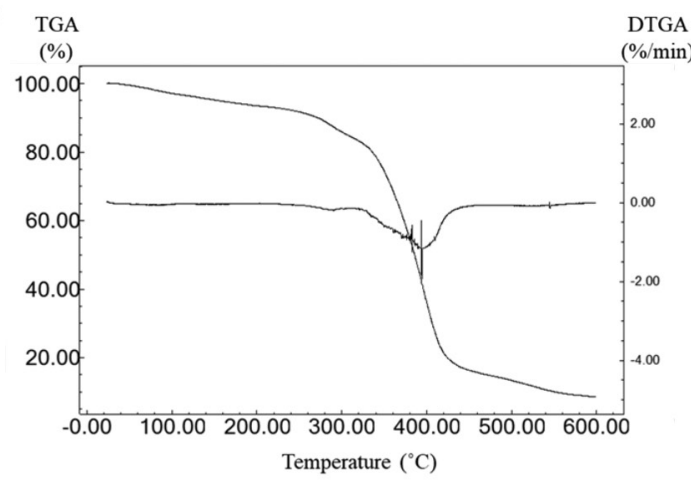

c)

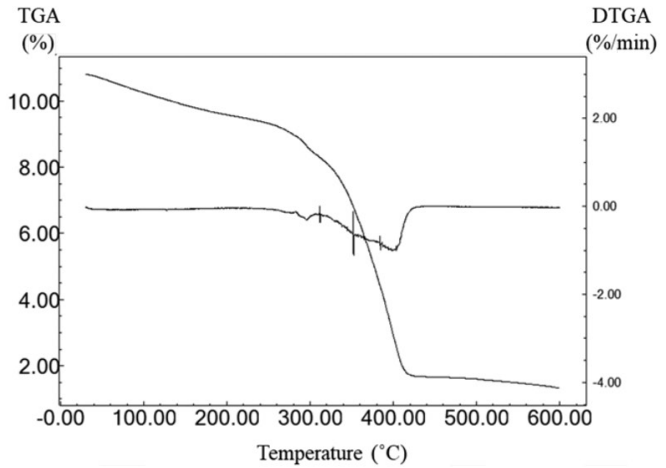

b)

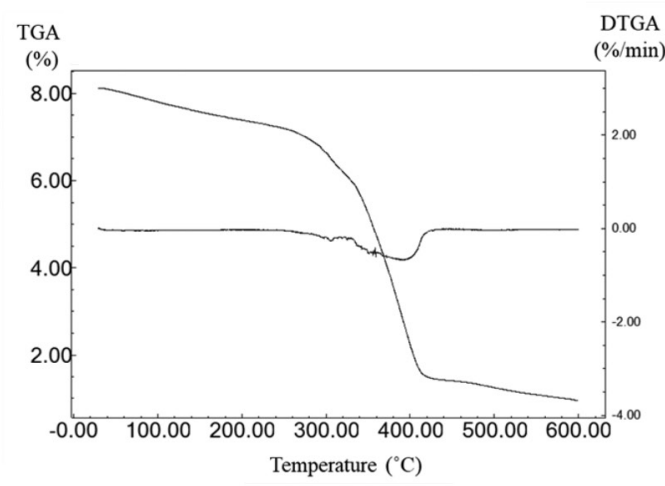

d)

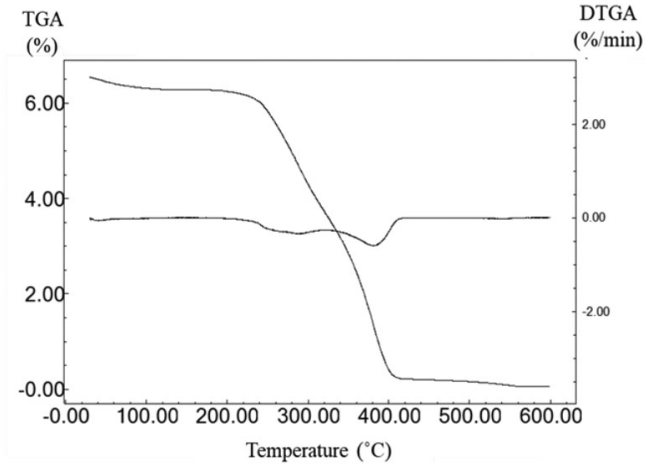

FIGURE 4. TGA/DTGA curves of PEG-PDMS crosslinked copolymers; a) 5E2D b) 6E2D c) 7E1D and d) PEG 1,500 
Thermogravimetric analysis was conducted to determine the thermal degradation stability of the copolymers. The TGA and DTGA curves of PEG-PDMS crosslinked copolymers were compared with PEG 1,500 homopolymer, and are shown in Figure 4. Based on the TGA curves in Figure 4, it showed that the small loss of weight at $100^{\circ} \mathrm{C}$ can be attributed to the loss of moisture. The degradation of the copolymers occurred at higher temperatures compared to PEG 1,500. From the DTG data, the PEG homopolymer used to prepare the copolymer exhibited maximum rate of weight loss at $390^{\circ} \mathrm{C}$, whereas the maximum weight loss of the copolymers occurred at higher temperatures of $388^{\circ} \mathrm{C}$ for copolymer $5 \mathrm{E} 3 \mathrm{D}, 360^{\circ} \mathrm{C}$ for $6 \mathrm{E} 2 \mathrm{D}$ and $359^{\circ} \mathrm{C}$ for $7 \mathrm{E} 1 \mathrm{D}$. It can be said that the thermal stability of the copolymers is better compared to the homopolymer. The 5E3D copolymer degrades at higher temperature followed by $6 \mathrm{E} 2 \mathrm{D}$ and $7 \mathrm{E} 1 \mathrm{D}$.

\section{CONCLUSION}

Three poly(ethylene glycol)-polydimetylsiloxane crosslinked copolymers with different weight ratio of PEG:PDMS were synthesized. The copolymers were synthesized by the reaction of hydroxyl groups of PEG, PDMS and glycerol with isocyanate groups of HMDI. The addition of glycerol in the reaction caused the formation of crosslinked copolymers. FTIR spectroscopy has confirmed that the reaction of hydroxyl and isocyanate groups have taken place. The values of $\mathrm{T}_{\mathrm{m}}$ and $\mathrm{T}_{\mathrm{g}}$ for PEG and PDMS segments in the copolymers have been obtained by DSC. A trend was seen for the $T_{m}$ and $T_{g}$ of the PDMS segment. The temperatures decreased with the decreasing of mol ratios of PDMS. Meanwhile, the degradation stability of the copolymers increases as the mol ratio of PDMS was increased.

\section{ACKNOWLEDGEMENTS}

The authors would like to thank the Malaysian Government and Universiti Kebangsaan Malaysia (UKM) for the research grant FRGS/2/2014/SG06/UKM/02/1 as well as Gifu University (Japan). Ain would like to thank the Public Service Department of Malaysia (JPA) and Japan Student Services Organization (JASSO) for the scholarships.

\section{REFERENCES}

Askari, F., Barikani, M., Barmar, M., Shokrolahi, F. \& Vafayan, M. 2015. Study of thermal stability and degradation kinetics of polyurethane-ureas by thermogravimetry. Iran Polym. $J$. 24(9): 783-789.

Badri, K., Mohd Dawi, L.I. \& Abd Aziz, N.A. 2013. Rigid polyurethane foam from glycolysed polyethylene terephthalate dissolved in palm-based polyol. Sains Malaysiana 42(4): 449-457.

Chattopadhyay, D.K. \& Webster, D.C. 2009. Thermal stability and flame retardancy of polyurethanes. Prog. Polym. Sci. 34: 1068-1133.
Chuang, F., Tsen, W. \& Shu, Y. 2004. The effect of different siloxane chain-extenders on the thermal degradation and stability of seg-mented polyurethanes. Polym. Degrad. Stab. 84: 69-77.

Clarson, S.J. \& Semlyen, J.A. 1993. Siloxane Polymers. Englewood Cliffs, NJ: Prentice Hall.

Hamdani, S., Longuet, C., Perrin, D., Lopez-cuesta, J.M. \& Ganachaud, F. 2009. Flame retardancy of silicone-based materials. Polym. Degrad. Stab. 94: 465-495.

Hong, Y., Guan, J., Fujimoto, K.L., Hashizume, L., Pelinescu, A.L. \& Wagner, W.R. 2010. Tailoring the degradation kinetics of poly(ester carbonate urethane)urea thermoplastic elastomers for tissue engineering scaffolds. Biomaterials 31(15): 4249-4258.

Hood, M.A., Wang, B., Sands, J.M., La Scala, J.J., Beyer, F.L. \& Li, C.Y. 2010. Morphology control of segmented polyurethanes by crystallization of hard and soft segments. Polymer 51: 2191-2198.

Król, P., Pielichowska, K. \& Byczynski, L. 2010. Thermal degradation kinetics of polyurethane-siloxane anionomers. Thermochim Acta 91: 507-508.

Kawai, F. 1987. The biochemistry of degradation of polyethers. Crit. Rev. Biotechnol. 6(3): 273-307.

Kawai, F. \& Enokibara, S. 1996. Symbiotic degradation of polyethylene glycol (peg) 20,000-phthalate polyester by phthalate ester- and peg 20,000-utilizing bacteria. J. Ferment. Bioeng. 82(6): 575-579.

Rangel-Vazquez, N.A. \& Sanchez-Lopez, C. 2014. Spectroscopy analyses of polyurethane/polyaniline IPN using computational simulation (Amber, MM+ and PM3 Method). Polimeros 24(4): 453-463.

Shokrolahi, F. \& Yeganeh, H. 2014. Soft segment composition and its influence on phase-separated morphology of PCL/ PEG-based poly(urethane urea)s. Iran Polym. J. 23: 505-512.

Sung-Il, L., Youn-Sik, L., Kee, S.N., Yoon, B.H. \& Seuk-Beum, K. 2000. Degradable polyurethanes synthesized from poly(butylene succinate) polyol, poly(ethylene glycol), and 4,4'-Methylenebis(cyclohexyl isocyanate). Bull. Korean Chem. Soc. 21(11): 1145-1148.

Tyagi, D., Yilgor, I., McGrathm, J.E. \& Wilkes, G.L. 1984. Segmented organosiloxane copolymers. 2. Thermal and mechanical properties of siloxane-urea copolymers. Polymer 25: $1807-1816$.

Wang, C.B. \& Cooper, S.L. 1983. Morphology and properties of segmented polyether polyurethaneureas. Macromolecules 16: 775-786.

Wang, F., Li, Z., Lannutti, J.L., Wagner, W.R. \& Guan, J. 2009. Synthesis, characterization and surface modification of low moduli poly(ether caarbonate urethane)ureas for soft tissue engineering. Acta Biomater. 5: 2901-2912.

Wong, C.S. \& Badri, K. 2010. Sifat terma dan kerintangan api poliuretana berasaskan minyak isirung sawit dan minyak kacang soya. Sains Malaysiana 39(5): 775-784.

Wu, L., You, B., Li, D. \& Qian, F. 2000. The in vitro and in vivo stability of poly(urethane urea)s as biomedical materials. Polym. Degrad. Stab. 70: 65-69.

Yeh, J.T. \& Shu, Y.C. 2010. Characteristics of the degradation and improvement of the thermal stability of poly(siloxane urethane) copolymers. J. Appl. Polym. Sci. 115: 2616-2628.

Zhang, X.M., Li, L. \& Zhang, Y. 2013. Study on the surface structure and properties of PDMS/PMMA antifouling coatings. Physics Procedia. 50: 328-336. 
Ain Athirah Zainuddin, Rizafizah Othaman, Wan Syaidatul Aqma Wan Mohd Noor \& Farah Hannan Anuar*

School of Chemical Sciences and Food Technology

Faculty of Science and Technology

Universiti Kebangsaan Malaysia

43600 UKM Bangi, Selangor Darul Ehsan

Malaysia

Takeno Akiyoshi \& Takahashi Shinya

Department of Chemistry and Biomolecular Science

Faculty of Engineering, Gifu University

1-1 Yanagifo, Gifu-shi, Gifu 501-1193

Japan
*Corresponding author; email: farahhannan@ukm.edu.my

Received: 15 September 2017

Accepted: 28 November 2017 